\title{
Functional study and regional mapping of 44 hormono-regulated genes isolated from a porcine granulosa cell library
}

\author{
Gwenola Tosser-KlopP*, Agnès Bonnet, \\ Martine Yerle, François Hatey \\ Laboratoire de génétique cellulaire, Institut national de la recherche agronomique, \\ BP 27, 31326 Castanet-Tolosan Cedex, France
}

(Received 12 May 2000; accepted 31 August 2000)

\begin{abstract}
DNA clones from a pig granulosa cell cDNA library were isolated by differential hybridisation for follicle stimulating hormone (FSH) regulation in granulosa cells in a previous study. The clones that did not match any known sequence were studied for their expression in granulosa cells (treated or not by FSH) and in fresh isolated ovarian follicles mainly by comparative RT-PCR analysis. These results give functional data on genes that may be implicated in follicular growing. These ESTs have been localised on the porcine genome, using a somatic cell hybrid panel, providing new type I markers on the porcine map and information on the comparative map between humans and pigs.
\end{abstract}

pig / ovarian follicle / cDNA mapping / comparative RT-PCR / comparative map

\section{INTRODUCTION}

Folliculogenesis is defined as the development of ovarian follicles, leading either to ovulation or, more frequently, to atresia. Follicular development is regulated by hormonal networks where the pituitary hormones play a central role, locally modulated at least by intraovarian peptides. Since granulosa cells play a major role in follicular function and can be easily isolated from follicles, they have been extensively studied in several species including pigs and are used as an in vitro model for understanding follicular development $[4,16,23]$. The effects of follicle stimulating hormone (FSH) treatment on granulosa cells in culture have been studied in depth: FSH induces the stimulation of various key genes in folliculogenesis and steroidogenesis, e.g. P450 scc [10].

This cell culture model was used to construct a cDNA library and to isolate FSH-regulated genes. A hundred and thirty-six expressed sequence tags (ESTs) were isolated, 82 of which could not be identified by comparing them with

\footnotetext{
${ }^{*}$ Correspondence and reprints

E-mail: tosser@toulouse.inra.fr
} 
sequences stored in the databases in 1996 [24]. In 2000, only seven of them had a putative identification. These ESTs are of interest since they represent a source of new genes. Moreover, the reason they have not been isolated in humans may be that the process of reproduction is difficult to study with functional ovaries.

A functional analysis of these genes was therefore carried out, by Northern blot or comparative RT-PCR to demonstrate the regulation of the corresponding mRNA in either cultured granulosa cells (different conditions) or in wellcharacterised isolated follicles.

In pigs, genetic and cytogenetic maps have been developed mainly by mapping anonymous polymorphic markers like microsatellites. Several strategies were then developed to obtain information on the correspondences between the genomes of pigs and other mammals.

The conservation of large segments of the mammalian genome between humans and pigs has been demonstrated through heterologous hybridisation approaches $[7,9,21]$. However, within these segments, the order of the genes is not always maintained, some very small segments may not be detected and the limits of the regions are not very precisely determined.

Consequently, expressed genes are needed as markers, since they are generally well conserved between species, especially between pigs and humans, and are a source of candidate genes for the zootechnical functions studied. cDNAs thus represent a powerful tool since a great number of cDNAs have been isolated and located on the human genome and the information is available through databases. Lahbib-Mansais et al. [14] demonstrated that human sequences are useful (even if the success rate of heterologous amplification is low) for mapping cDNAs onto the pig genome. In pigs, 532 genes have been localised on the cytogenetic map (http://www.toulouse.inra.fr/lgc/pig/cyto/genes.htm).

In the last few years, several tissue-specific pig libraries have been constructed and used in regional localisation with the somatic-cell hybrid made available by $M$. Yerle et al. [28]. A library of the small intestine [26] enabled the localisation of 89 new porcine genes $[6,13,27]$. A project is under way to localise $700 \mathrm{cDNAs}$ on the porcine genome by using this panel [8].

Since several regions of the pig genome are involved in production traits $[1$, 25 , it would be interesting to localise the genes isolated from our cDNA library on the porcine genome. These genes may become candidate genes for reproduction traits. In this study, $44 \mathrm{cDNAs}$ were localised on the porcine genome. This also provides new data for comparing pig and human genomes when a human sequence is found.

\section{MATERIALS AND METHODS}

\subsection{Clones and primers}

The eighty-two potentially hormono-regulated clones that had already been sequenced but not identified [24] were studied. The Codonpreference program of the Wisconsin Genetic Computer Group software package (GCG Package, Wisconsin Package, Version 9.1, September 1997, Genetics Computer Group, 
Madison, Wisconsin 53711, USA) was used to predict ORFs (Open Reading Frame) in the ESTs, in order to select the primers in the $3^{\prime} U T R$, if possible. The primers were selected by the use of the Prime program (GCG Package) in order to amplify 85 to 286 bp products. The primers are listed in Table I.

\subsection{Obtainment of granulosa cells or follicles and RNA extraction}

The culture conditions and RNA extraction of granulosa cultured cells have been described previously [24].

For the study of fresh calibrated follicles, follicles were isolated from swine 24 or $96 \mathrm{~h}$ after the end of altrenogest (a progesterone agonist) treatment, (REGUMATE; Hoechst-Roussel Agri-Vet Company, Somerville, NJ, $20 \mathrm{mg}$ per day for 18 days). The diameter of the follicles was measured and they were classified as follows: small ( 1 to $2 \mathrm{~mm}$ in diameter), medium (3 to $4 \mathrm{~mm}$ ), and large $(5$ to $8 \mathrm{~mm}$ ) follicles. The granulosa cells were collected as with cell culture experiments and a few cells were examined as described by Monget et al. [18] to determine the physiological status of the follicles.

The RNA was extracted from the granulosa cells of healthy follicles with the Rneasy kit (Qiagen) using pools of follicles of the same class (8 to 20 samples, depending on the follicle diameter) and treated by DNase I for $30 \mathrm{~min}$ at $37^{\circ} \mathrm{C}$ ( $1 \mathrm{U} / \mathrm{mg}$ of RNA, Boehringer). Then RNA was reextracted using the same purification kit.

\section{3. cDNA synthesis, comparative RT-PCR, and tissue analysis}

Total DNase I treated RNA (2 $\mu \mathrm{g})$ was reverse transcribed in a $20 \mu \mathrm{L}$ reaction by using $100 \mathrm{pmol}$ of a dT15 oligonucleotide with Superscript II kit (Life Technologies), and $0.5 \mu \mathrm{Ci}$ of $\alpha^{32} \mathrm{P}$ labeled dCTP (specific activity $>3000 \mathrm{Ci} \cdot \mathrm{mmol}^{-1}$, Dupont de Nemours) was added to monitor the transcription. After one hour of incubation at $37^{\circ} \mathrm{C}$, the RNA was hydrolyzed by adding $10 \mu \mathrm{L}$ of $0.9 \mathrm{~N} \mathrm{NaOH}$ and incubating 15 min at $65^{\circ} \mathrm{C}$. The reaction was neutralized by adding $15 \mu \mathrm{L}$ of $0.9 \mathrm{~N}$ acetic acid and $53 \mu \mathrm{L}$ of distilled water. The first strand cDNAs were purified by G50 chromatography and quantified by measuring the radioactivity incorporated. From each cDNA sample (control and FSH-treated cells, small, medium, or large healthy follicles) the same dilutions of cDNA were made: $2 \mathrm{pg} \cdot \mu \mathrm{L}^{-1}, 10 \mathrm{pg} \cdot \mu \mathrm{L}^{-1}, 50 \mathrm{pg} \cdot \mu \mathrm{L}^{-1}$, and $200 \mathrm{pg} \cdot \mu \mathrm{L}^{-1}$. The number of cycles in the PCR was selected so as to fall within the exponential phase of the amplification reaction, for at least two dilutions. Master mixes were prepared and each PCR amplification (30 $\mu \mathrm{L}$ final reaction volume) was carried out with $5 \mu \mathrm{L}$ of each dilution of first strand cDNA, $1 \mu \mathrm{M}$ of each specific primer, $200 \mu \mathrm{M}$ of each dNTP, 1.5 or $2.5 \mathrm{mM} \mathrm{MgCl}$ and 2 units of Taq DNA polymerase (Life Technologies), in the buffer provided by the manufacturer. PCR amplifications were performed on a PHC 3 thermocycler (Techne) as follows: denaturation $5 \mathrm{~min}$ at $94^{\circ} \mathrm{C}$, followed by at least 25 cycles of $\left(1 \mathrm{~min}\right.$ at $94^{\circ} \mathrm{C}, 30 \mathrm{~s}$ at the specific hybridisation temperature of each primer pair, $30 \mathrm{~s}$ at $72^{\circ} \mathrm{C}$ ). The number of cycles of amplification depends 


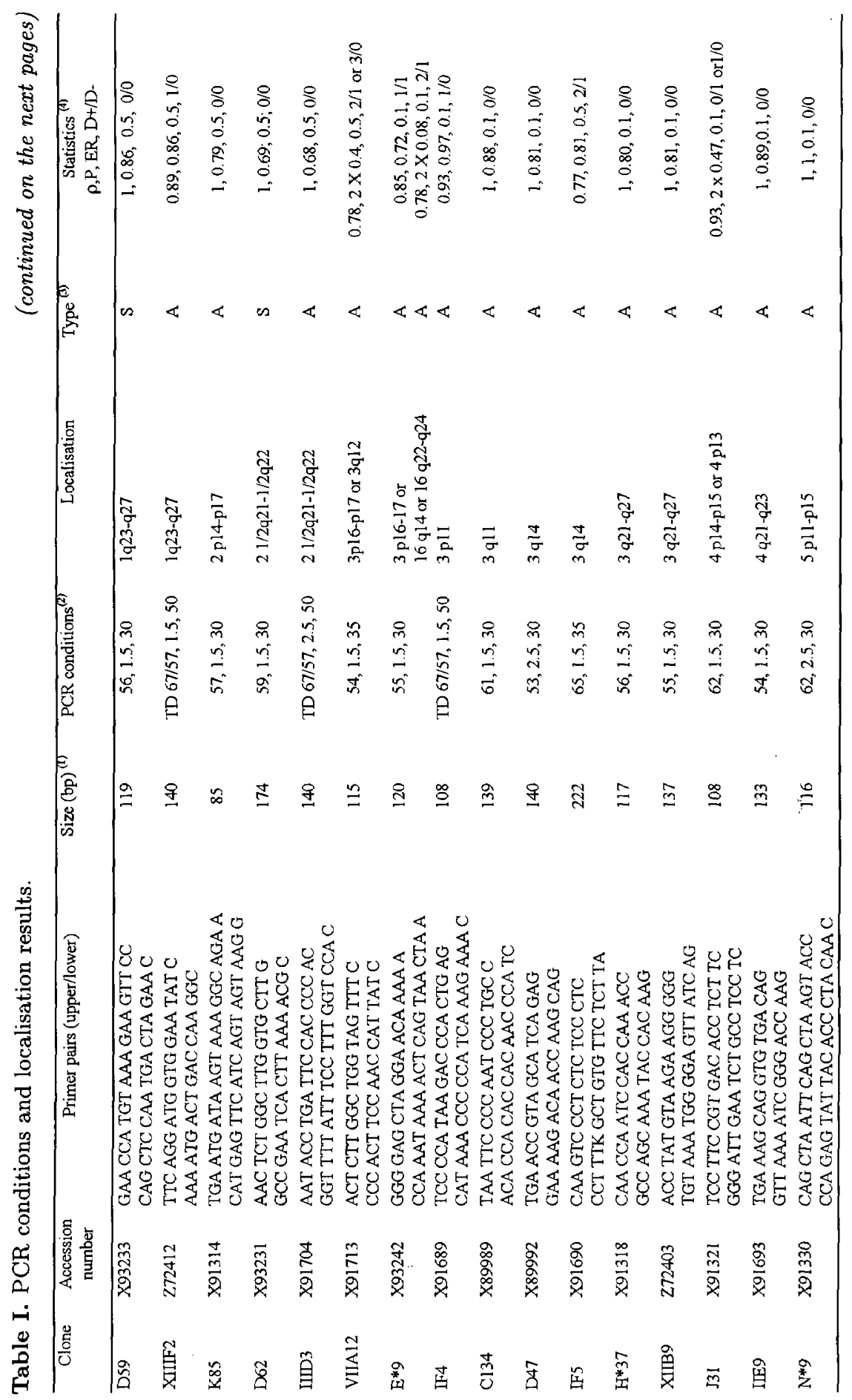




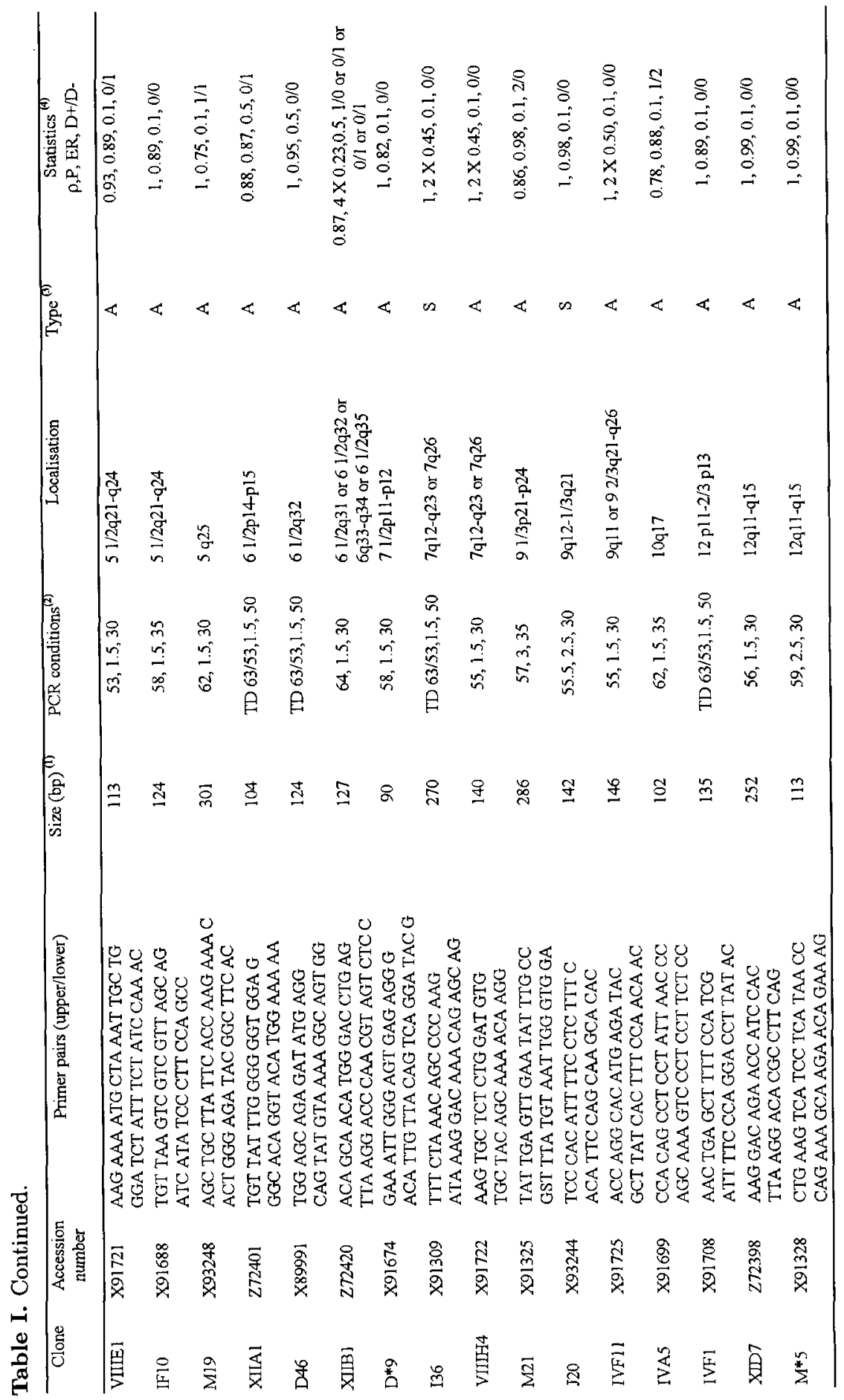




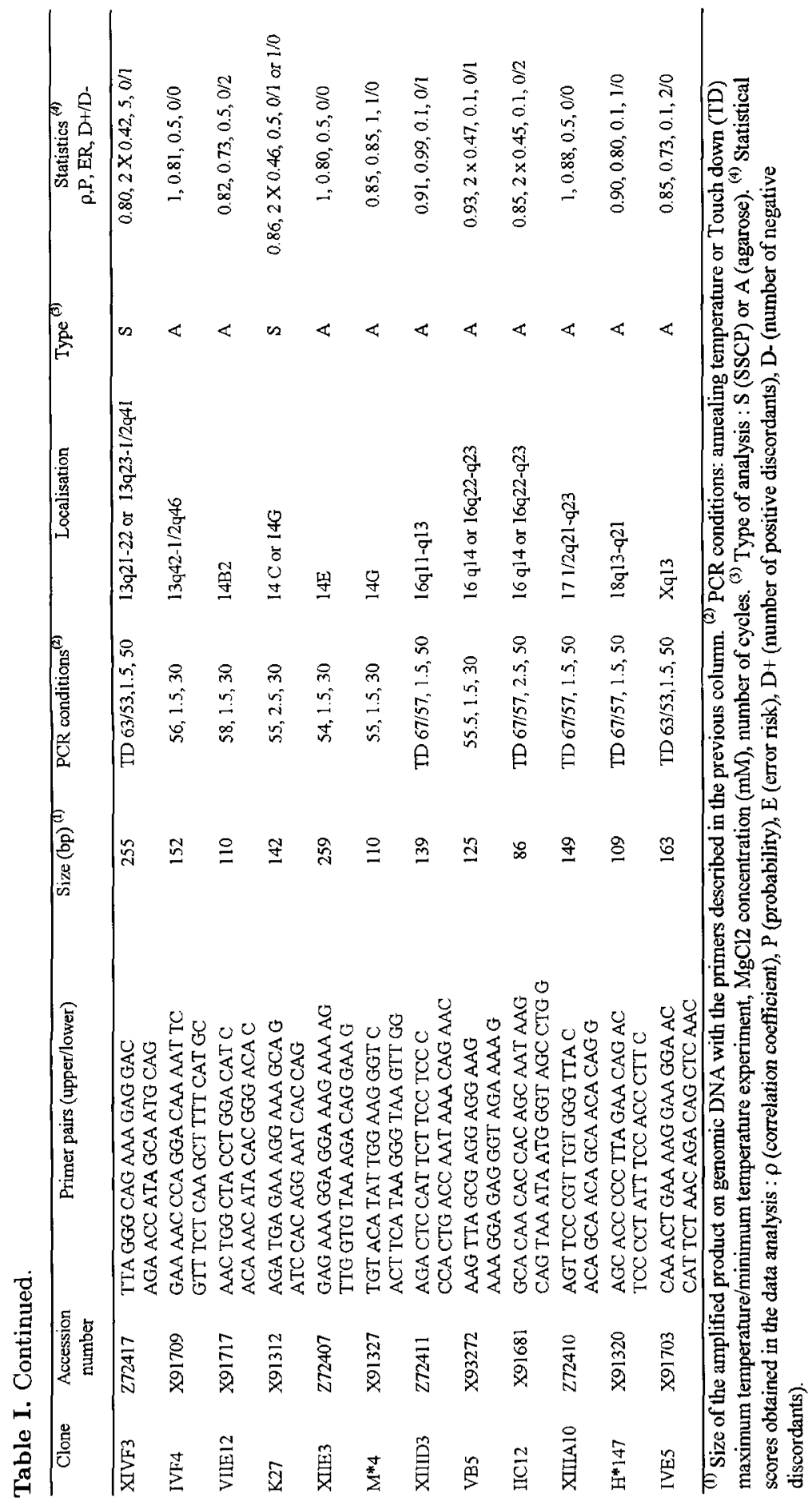


on the abundance of the cDNA (27 to 36 cycles). Fifteen $\mu \mathrm{L}$ of PCR products were analyzed by electrophoresis on $1 \%$ agarose gel. cDNA quantification and dilutions were tested using 2 internal standards: the P450scc, the Insulinlike Growth Factor I (IGF I) and as an external standard a plant messenger RNA: I11a [2]. P450scc and IGF1 which are up regulated by FSH $[10,11]$ were analyzed using the same cDNA dilutions. Analysis of the data indicated that FSH increased the mRNA levels by a factor of at least 5. I11a mRNA was added to the RNA ( $200 \mathrm{fg}$ for $2 \mu \mathrm{g}$ RNA sample) in order to check that the specific amplification of the corresponding cDNA gave an equal signal in control and FSH-treated cells. The primers are described in Table I and the PCR conditions in Table II. The experiments were performed at least twice.

\subsection{Regional assignment on somatic cell hybrid panel}

The optimization of the PCR conditions was performed on $50 \mathrm{ng}$ of pig, hamster, mouse, and human DNA or $1 \mathrm{ng}$ of plasmid DNA in $25 \mu \mathrm{L}$ using $0.5 \mu \mathrm{M}$ of each primer, $100 \mu \mathrm{M}$ of each dNTP, $0.5 \mathrm{U}$ of Life Technologies Taq polymerase, in the buffer provided by the manufacturer. The first experiments were carried out with different concentrations of $\mathrm{MgCl}_{2}$ (1 to $3 \mathrm{mM}$ ) and annealing temperatures, using thirty to thirty-five cycles (annealing temperature $30 \mathrm{~s}$ $-72^{\circ} \mathrm{C} 30 \mathrm{~s}-94^{\circ} \mathrm{C} 30 \mathrm{~s}$ ) with an initial 5-min denaturation step and a final 10-min elongation step. If no amplification was observed for pig DNA in these conditions, touch down (TD) conditions were used: $5 \times 3$ cycles were effected with an annealing temperature decreasing from $67^{\circ} \mathrm{C}$ or $63^{\circ} \mathrm{C}$ down to $59^{\circ} \mathrm{C}$ or $55^{\circ} \mathrm{C}$ in two-degree steps and then thirty-five cycles were performed at either $57^{\circ} \mathrm{C}$ or $53^{\circ} \mathrm{C}$. This optimization step enabled a product of amplification with pig DNA and no amplification with rodent DNA, or products that could be differentiated by either agarose or SSCP analysis.

The panel used for the regional assignments consisted of $19 \mathrm{pig} \times$ hamster and 8 pig $\times$ mouse hybrid cell lines (Yerle et al. $[28]$ ). The PCR conditions determined above were used on $50 \mathrm{ng}$ of each hybrid using pig and rodent DNA as controls. $10 \mu \mathrm{L}$ of the PCR reactions were analysed on $2 \%$ agarose gel or, when necessary, in SSCP with silver staining [15].

Each hybrid was then scored for the presence of a pig specific DNA fragment and the assignments were performed, using software that calculates the probability of the localisation of a marker among the 115 regions of the porcine genome determined by this panel

(http://www.toulouse.inra.fr/lgc/pig/pcr/pcr.htm, $[3,22]$ ).

\subsection{Sequence comparison and comparative map with humans}

For each clone, the sequence data were analysed with the FASTA program [19] for similarities with known sequences in the entire Genbank (release 110, 12/98) and EMBL (release 56, 09/98) databases. The most significant similarities (more than $80 \%$ identity using the $5^{\prime}$ end sequence of a clone and more than $75 \%$ identity using the $3^{\prime}$ end) were further used to collect data on human mapping. Different sources of information were used:

the TIGR database (http://www.tigr.org/index.html), 
Unigene (http://www.ncbi.nlm.nih.gov/UniGene/Hs.Home.html) and the Gene Map 98 (http://www.ncbi.nlm.nih.gov/genemap).

\section{RESULTS}

Eleven of the 82 clones studied did not permit the selection of appropriate primers, because either inserts were too short or the melting point of the sequence was too low. Of the 71 primer pairs tested on porcine genomic DNA, 24 either failed to amplify or produced several non-specific bands. The other 47 (66\%) amplified pig DNA and were used for regulation and localisation studies.

\subsection{Regulation studies}

The regulation studies using Northern blot analysis proved to be difficult, since only 8 out of the 24 genes analysed gave an interpretable result (data not shown). The other 16 probes either gave too weak a signal, no signal or a signal that was not interpretable (Tab. II). Consequently a study of the regulation of these genes by RT-PCR analysis was undertaken.

Forty genes were tested by this method, using control or FSH-stimulated granulosa cells (Tab. II). Fourteen clones were stimulated by FSH (among them, three that had already proven to be stimulated by Northern blot analysis), one was down-regulated by FSH (confirmed by Northern blot analysis). The level of expression of the remaining 25 was not changed by FSH.

FSH stimulation is illustrated in Figure 1. Figure 1A shows that the signals of amplification of an exogenous control mRNA were identical for FSH-treated cells (250 pg of cDNA in lane c and $1 \mathrm{ng}$ in lane d) or control cells (250 pg of cDNA in lane $\mathrm{g}$ and $1 \mathrm{ng}$ in lane $\mathrm{h}$ ). Figure $1 \mathrm{~B}$ shows that for the P450scc gene, a signal was obtained in a 27-cycle PCR reaction on $50 \mathrm{pg}$ (lane b), $250 \mathrm{pg}$ (lane c) or $1 \mathrm{ng}$ (lane d) of cDNA from FSH-treated cells and only in reactions containing $250 \mathrm{pg}$ (lane g) or $1 \mathrm{ng}$ (lane h) of cDNA from control cells. For the IGF1 gene, similar results, showing an up-regulation of the gene by FSH were obtained (data not shown). Using the same cDNA preparations for the VIIIH4 gene (Fig. 1C), we obtained a signal in a 31-cycle PCR reaction on $250 \mathrm{pg}$ (lane c) or $1 \mathrm{ng}$ (lane d) of cDNA from FSH-treated cells and only in reactions containing $1 \mathrm{ng}$ (lane $\mathrm{h}$ ) of cDNA from control cells, indicating an approximately 4-fold stimulation by FSH.

Twelve of the 15 regulated clones were tested by RT-PCR analysis on the granulosa cells of freshly isolated porcine follicles. Six of these gave a differential signal, depending on the state of development of the follicle. Figure 1D shows that VIIIH4 was expressed at a higher level in large follicles (lanes a to d) and in small follicles harvested $96 \mathrm{~h}$ post Regumate treatment (lanes i to l) than in medium-size follicles (lanes e to $\mathrm{h}$ ) or in small follicles harvested $24 \mathrm{~h}$ post Regumate treatment (lanes $\mathrm{m}$ to $\mathrm{p}$ ).

\subsection{Regional assignment using the somatic hybrid panel}

Of the 47 primer pairs that amplified the pig DNA, one (M19) resulted in the amplification of a longer fragment than the fragment obtained with the plasmid 
Table II. Regulation studies.

(continued on the next page)

\begin{tabular}{|c|c|c|c|c|c|}
\hline \multirow[t]{2}{*}{ Clone } & \multirow[t]{2}{*}{ Putative identification } & \multirow{2}{*}{$\begin{array}{c}\text { PCR } \\
\text { conditions (1) }\end{array}$} & \multirow[t]{2}{*}{ Northem (2) } & \multicolumn{2}{|c|}{ RT-PCR results (3) } \\
\hline & & & & cells & follicles \\
\hline$\overline{\mathrm{D} 59}$ & $\overline{\mathrm{UBA} 3}$ & $56,1.5,30$ & NT & $\mathrm{FSH}>\mathrm{T}$ & SF24=SF96=MF24=LF96 \\
\hline XIIIF2 & rabl la GTPase & $53,1.5,29$ & NT & $\mathrm{FSH}=\mathrm{T}$ & \\
\hline K85 & FGFR4 & $60,1.5,30$ & NT & $\mathrm{FSH}>\mathrm{T}$ & SF24=SF96=MF24=LF96 \\
\hline D62 & & $59,1.5,30$ & NT & $\mathrm{FSH}>\mathrm{T}$ & $\mathrm{SF} 24=\mathrm{SF} 96=\mathrm{MF} 24=\mathrm{LF} 96$ \\
\hline IIID3 & & $62,1.5,28$ & $\mathrm{~T}>\mathrm{FSH}$ & $\mathrm{T}>\mathrm{FSH}$ & \\
\hline VIIA12 & & $56,1.5,30$ & $\mathrm{~T} \gg \mathrm{FSH}$ & $\mathrm{FSH}=\mathrm{T}$ & \\
\hline$E^{*} 9$ & & $56,1.5,36$ & $\mathrm{FSH}>\mathrm{T}$ & $\mathrm{FSH}>\mathrm{T}$ & \\
\hline IF4 & KIAA0183 gene & ND & $\mathrm{FSH}=\mathrm{T}$ & & \\
\hline $\mathrm{C} 134$ & & $61,1.5,30$ & NT & $\mathrm{FSH}=\mathrm{T}$ & \\
\hline D47 & & $54,1.5,30$ & NT & $\mathrm{FSH}=\mathrm{T}$ & \\
\hline IF5 & & $57,1.5,27$ & $\mathrm{FSH}>\mathrm{T}$ & $\mathrm{FSH}>\mathrm{T}$ & \\
\hline $\mathrm{H} * 37$ & & $56,1.5,28$ & $\mathrm{NC}$ & $\mathrm{FSH} \gg \mathrm{T}$ & $\mathrm{SF} 24=\mathrm{SF} 96=\mathrm{MF} 24=\mathrm{LF} 96$ \\
\hline XIIB9 & & $55,1.5,31$ & NT & $\mathrm{FSH}=\mathrm{T}$ & \\
\hline $\mathrm{J} 31$ & & ND & $\mathrm{NC}$ & & \\
\hline IIE9 & & $54,1.5,29$ & $\mathrm{NC}$ & $\mathrm{FSH}>\mathrm{T}$ & $\mathrm{SF} 24=\mathrm{SF} 96=\mathrm{MF} 24=\mathrm{LF} 96$ \\
\hline $\mathrm{N}^{* 9}$ & & $62,2.5,33$ & NC & $\mathrm{FSH}>\mathrm{T}$ & SF96>SF24=MF24=LF96 \\
\hline VIIIEl & & $55,1.5,35$ & NT & $\mathrm{FSH}>\mathrm{T}$ & $\mathrm{SF} 96>\mathrm{SF} 24=\mathrm{MF} 24=\mathrm{LF} 96$ \\
\hline IF 10 & $\begin{array}{c}\text { Methionine } \\
\text { aminopeptidase }\end{array}$ & $56,1.5,31$ & $\mathrm{FSH}>\mathrm{T}$ & $\mathrm{FSH}>\mathrm{T}$ & \\
\hline M19 & DRIM protein & $62,2.5,31$ & $\mathrm{NC}$ & $F S H=T$ & \\
\hline XIIAI & & $58,1.5,33$ & NT & $\mathrm{FSH}=\mathrm{T}$ & \\
\hline D46 & & $56,1.5,30$ & $\mathrm{NC}$ & $\mathrm{FSH}=\mathrm{T}$ & LF96 $>>S F 96>M F 24>S F 24$ \\
\hline XIIB1 & & $64,1.5,31$ & NT & $\mathrm{FSH}>\mathrm{T}$ & $\mathrm{SF} 96=\mathrm{MF} 24=\mathrm{LF} 96>\mathrm{SF} 24$ \\
\hline D*9 & & $\mathrm{ND}$ & NT & & \\
\hline 136 & 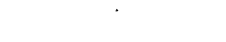 & $54,1.5,31$ & $\mathrm{~T}>\mathrm{FSH}$ & $\mathrm{FSH}=\mathrm{T}$ & \\
\hline VIIIH4 & & $55,1.5,31$ & NT & $\mathrm{FSH}>\mathrm{T}$ & $\mathrm{SF} 96=\mathrm{LF} 96>\mathrm{MF} 24>=\mathrm{SF} 24$ \\
\hline M21 & & $53,1.5,29$ & $\mathrm{FSH}=\mathrm{T}$ & $\mathrm{FSH}=\mathrm{T}$ & \\
\hline $\mathrm{J} 20$ & & $55.5,2.5,32$ & NT & $\mathrm{FSH}=\mathrm{T}$ & \\
\hline IVF11 & & $55,1.5,32$ & NC & $\mathrm{FSH}=\mathrm{T}$ & \\
\hline IVAS & D123 protein & $62,1.5,30$ & $\mathrm{NC}$ & $\mathrm{FSH}>\mathrm{T}$ & $\mathrm{SF} 24=\mathrm{SF} 96=\mathrm{MF} 24=\mathrm{LF} 96$ \\
\hline IVFI & & $55,1.5,30$ & $\mathrm{NC}$ & $\mathrm{FSH}=\mathrm{T}$ & \\
\hline XID7 & rabaptin-5 & $56,1.5,31$ & NT & $\mathrm{FSH}=\mathrm{T}$ & \\
\hline$M^{* 5}$ & & ND & NT & & \\
\hline XIVF3 & & $53,1.5,27$ & NT & $\mathrm{FSH}=\mathrm{T}$ & \\
\hline IVF4 & & $56,1.5,27$ & $\mathrm{NC}$ & $\mathrm{FSH}=\mathrm{T}$ & \\
\hline VIIE12 & & $58,1.5,28$ & NC & $\mathrm{FSH}=\mathrm{T}$ & \\
\hline $\mathrm{K} 27$ & KIAA0262 gene & $55,1.5,36$ & NT & $\mathrm{FSH}=\mathrm{T}$ & \\
\hline XIE3 & & $55,1.5,30$ & NT & $\mathrm{FSH}=\mathrm{T}$ & \\
\hline
\end{tabular}


Table II. Continued.

\begin{tabular}{|c|c|c|c|c|c|}
\hline \multirow[t]{2}{*}{ Clone } & \multirow[t]{2}{*}{ Putative identification } & \multirow{2}{*}{$\begin{array}{c}\text { PCR } \\
\text { conditions (1) }\end{array}$} & \multirow[t]{2}{*}{ Northern (2) } & \multicolumn{2}{|c|}{ RT-PCR results (3) } \\
\hline & & & & cells & follicles \\
\hline $\bar{M}{ }^{* 4}$ & & $55,1.5,33$ & $\mathrm{NC}$ & FSH $>\mathrm{T}$ & SF24=MF24<SF96=LF96 \\
\hline XIIID3 & $\begin{array}{l}\text { Highly similar to } \\
\text { elastin like protein }\end{array}$ & $59,1.5,26$ & $\mathrm{NC}$ & $\mathrm{FSH}=\mathrm{T}$ & \\
\hline VB5 & & $55.5,1.5,35$ & $\mathrm{NC}$ & $\mathrm{FSH}=\mathrm{T}$ & \\
\hline $\mathrm{IICl} 2$ & & $63,1.5,35$ & $\mathrm{NC}$ & $\mathrm{FSH}=\mathrm{T}$ & \\
\hline XIIIA.10 & & $58,1.5,29$ & NT & $\mathrm{FSH}=\mathrm{T}$ & \\
\hline $\mathrm{H}^{*} 147$ & & $60,1.5,35$ & NT & $\mathrm{FSH}=\mathrm{T}$ & \\
\hline IVES & & $58,1.5,30$ & $\mathrm{NC}$ & $\mathrm{FSH}=\mathrm{T}$ & \\
\hline
\end{tabular}

(1) PCR conditions: annealing temperature, $\mathrm{MgCl} 2$ concentration (mM), number of cycles or the experiment was not done (ND). ${ }^{(2)}$ Northern blot results: the gene was up-regulated (FSH>T), downregulated $(\mathrm{FSH}<\mathrm{T}$ ), not regulated $(\mathrm{FSH}=\mathrm{T})$ by $\mathrm{FSH}$, not conclusive $(\mathrm{NC})$ or the experiment was not done (NT) ${ }^{(3)}$ For RT-PCR results on cells, the same notation has been used as for Northern blot analysis.

Small follicles (SF), medium size follicles (MF) or large follicles (LF) were collected either $24 \mathrm{~h}$ (24) or $96 \mathrm{~h}(96)$ after the end of the treatment by Regumate.

control. This product was sequenced and was found to contain a small intron (about $200 \mathrm{bp}$ ) in addition to the expected sequence. For all other primer pairs, the product obtained had the expected size, ranging from 85 to $286 \mathrm{bp}$. For the seven primer pairs that allowed the amplification of the rodent DNA, the pig specific product was identified with the SSCP technique.

Forty-four clones were assigned with a probability $>0.72$ and a correlation coefficient $>0.75$. The other three were assigned with a correlation coefficient between 0.7 and 0.75 , this was considered insufficiently significant (data not shown). However, one of them, $\mathrm{E}^{*} 9$ was localised by the use of a porcine irradiated panel [29] on Sscr16 (data not shown) although the probability of this localisation was only 0.16 with the somatic cell hybrid panel. The results are listed in Table I, along with the correlation coefficient, the error risk, the probability of the localisation, and the number of discordant results (positive or negative). Among the 44 localisations presented here, 42 showed an error risk of less than $0.5 \%$, including 27 with an error risk $<0.1 \%$. Two markers (XIVF3 , error risk $<5 \%$ and $\mathrm{M}^{*} 4$, error risk $<1 \%$ ) had a higher error risk, due to a low number of positive hybrids in the region of localisation.

\section{DISCUSSION}

\subsection{Regulation studies}

This paper describes the successful use of comparative RT-PCR analysis. Forty-four ESTs were studied using this method. This approach was particularly useful since, in our experiments, Northern experiments have often failed (a failure rate of $80 \%$ ). This could be due to the low level of expression of many of the mRNAs, since they need a considerable number of cycles of amplification (about 30 ). In contrast to Northern blot analysis, RT-PCR does not give any information on the size of the mRNA corresponding to the EST, but it enables 

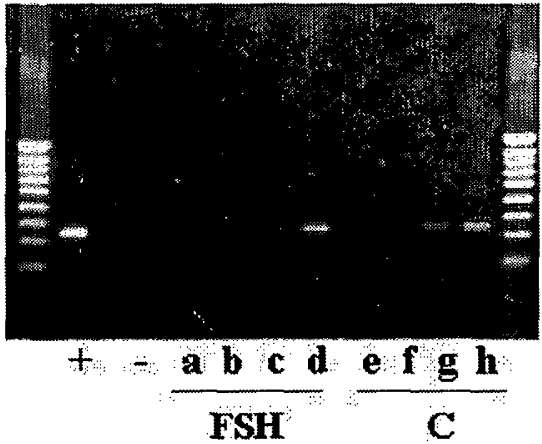

(1A)
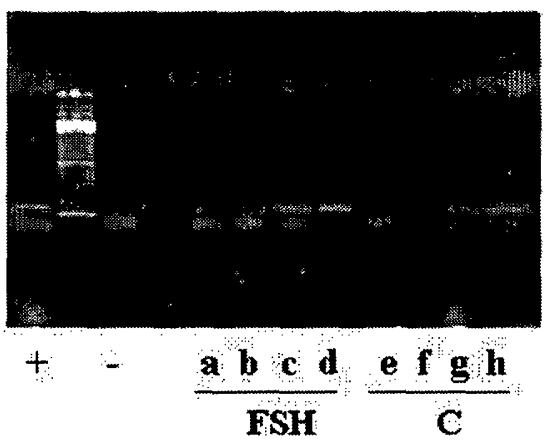

(1C)
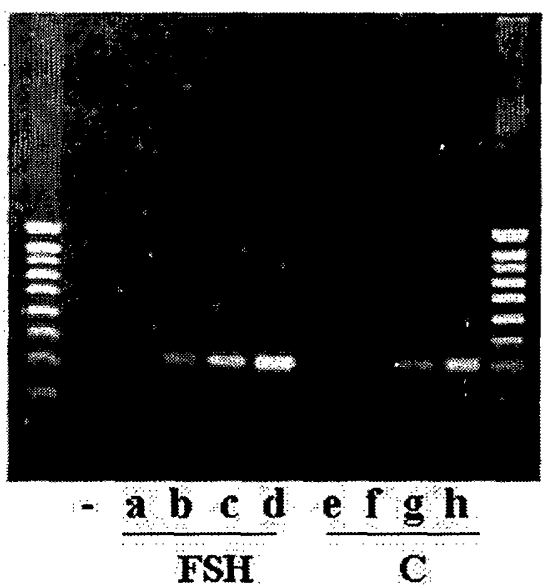

(1B)

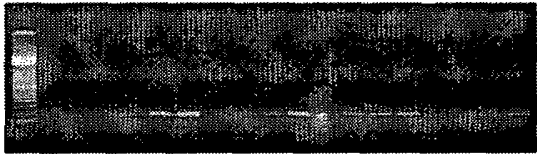

$\frac{\mathrm{abcd}}{\mathrm{LF} 96} \frac{\mathrm{efgh}}{\mathrm{MF24}} \frac{\mathrm{ijkl}}{\mathrm{SF} 96} \frac{\mathrm{mnop}}{\mathrm{SF} 24}$

(1D)

Figure 1. Comparative RT-PCR analysis study.

Total RNA extracted from control granulosa cells or FSH-treated cells (1A, 1B, 1C) or from small (SF), medium size (MF) or large (LF) ovarian follicles harvested 24 or $96 \mathrm{~h}$ post-Regumate treatment (1D) were reverse transcribed and four different quantities (10 pg, $50 \mathrm{pg}, 250 \mathrm{pg}, 1 \mathrm{ng}$ from left to right) of cDNA were used for a PCR amplification using specific primers.

Figure 1A shows the amplification of I11a gene, an external control mRNA.

Figure $1 \mathrm{~B}$ shows the amplification of the P450scc gene, which is up regulated in porcine granulosa cells.

Figure 1C and 1D show the amplification of VIIIH4, which is up regulated in FSHtreated cells, in comparison with control cells (1C) and in large and small size follicles harvested $96 \mathrm{~h}$ post Regumate treatment, in comparison with medium size and small size follicles harvested $24 \mathrm{~h}$ post Regumate treatment (1D).

faster analysis using less mRNA, with no radioactivity. Moreover, the PCR technique enables the study of many genes simultaneously by the use of 96 -well PCR plates. It allows the study of fresh follicles, which would not be possible by Northern blot experiments since very little mRNA can be extracted from this material. 
Since the development of the follicles is probably under the control of genes whose expression varies according to the size and the hormonal environment of the follicle, the genes that have been shown to be regulated according to the size of the follicle are of potential interest. Similarly, the study of follicles undergoing atresia would provide further data. However, so far, it has been difficult to obtain good quality mRNA from this material (data not shown).

More experiments should be carried out, in order to localise these transcripts more precisely, e.g. by in situ hybridisation of ovaries at different physiological stages. Moreover, this should give more accurate data on the time and localisation of the expression of these genes.

\subsection{Localisation of cDNA and comparative mapping}

This paper also describes forty-four regional localisations of previously unknown porcine genes on the pig genome, using a somatic cell hybrid panel. Whenever possible, primers were designed in a region predicted to be a $3^{\prime}$ UTR, a region that contains few introns [17] and that is highly polymorphic, in order to reduce the possibility of amplifying rodent DNA. Sixty-two percent of the sequences were localised, which is a standard rate: different teams using this somatic cell hybrid panel, mostly on identified genes, have described a success rate between $50 \%$ and $80 \%[6,13,27]$. Moreover, most of the localisations were obtained using agarose analysis and the PCR fragment had the expected size, with one exception.

Comparative data for the human genome were available for 22 of the 44 localisations reported in this paper (Tab. III). Fifteen localisations were in accordance with the data derived from the three experiments of heterologous painting approaches $[7,9,21]$, two were in accordance with the data derived from the first two experiments and five suggest new correspondences between pig and human genomes.

Localisations on Sscr4, Sscr6, Sscr7, Sscr10, Sscr12, Sscr13, and Sscr14 were in accordance with heterologous painting experiments and will not be discussed.

\subsection{Sscr1}

Sscr1q is in correspondence with Hsap 18, 15, 14, and 9.

The correspondence with Hsap 15 concerns the zones Sscr1 q13-q14 [21], q15-q18 [7,21], and q12-q22 [9]. The localisation of XIIIF2 on Sscr1 suggests an extension of the correspondence between Hsap 15 and Sscr1 to the Sscr 1 q23-q27 zone, and, probably to the top of this region (1 q23), since two other markers (MGAT2 [20] and H74180 [14]) located in the same pig region are located on Hsap14.

The localisation of D59 gave a new correspondence between Sscr1 and Hsap3, although available comparative data suggest a localisation on either Hsap9 or Hsap14. Our cDNA clone was $2000 \mathrm{bp}$-long and its sequence was very similar to the human one (more than $90 \%$ identity on $1300 \mathrm{bp}$ on the entire coding region and more than $80 \%$ on the $700 \mathrm{bp} 3^{\prime} \mathrm{UTR}$ ). 
Function and mapping of pig ovarian ESTs

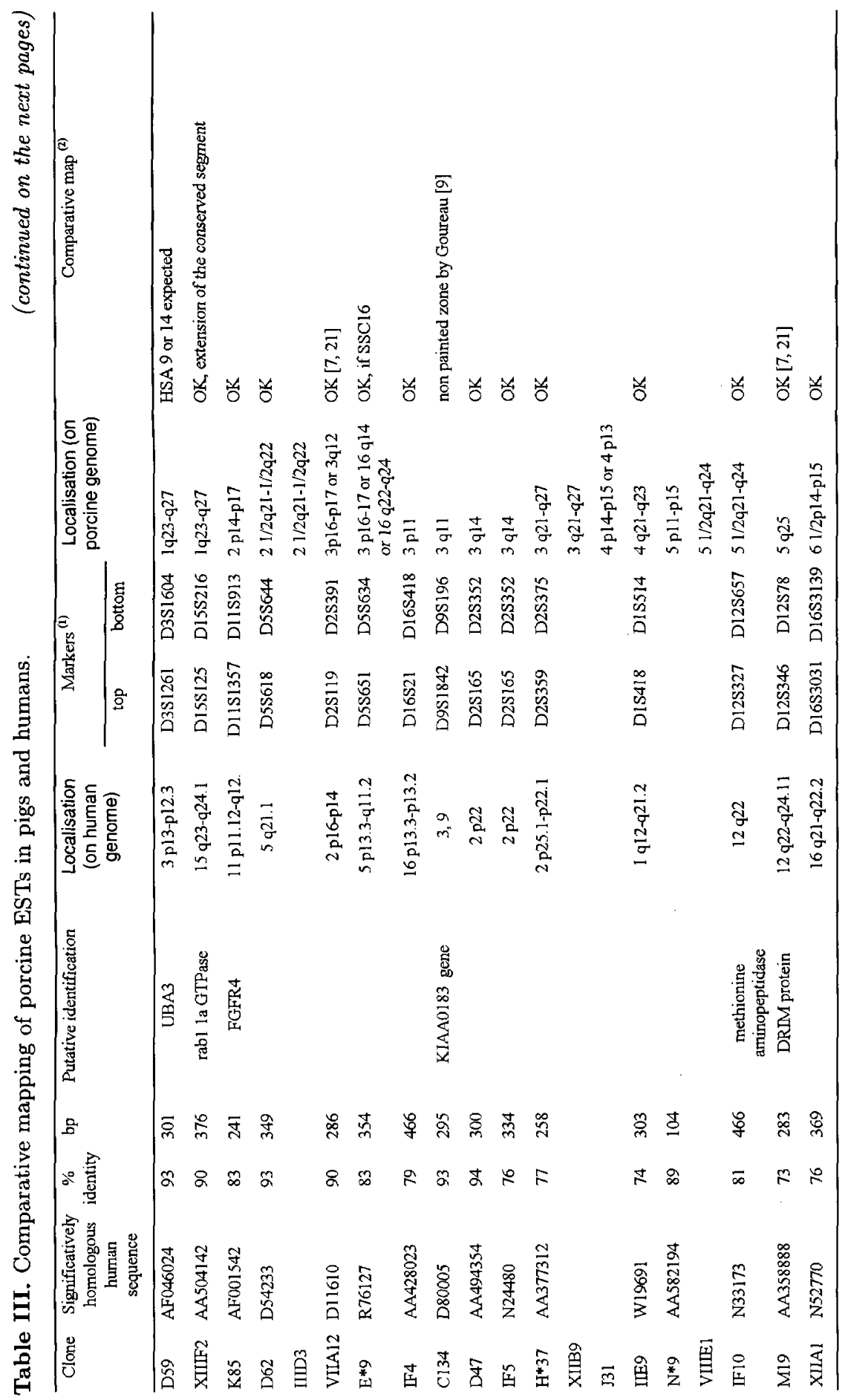




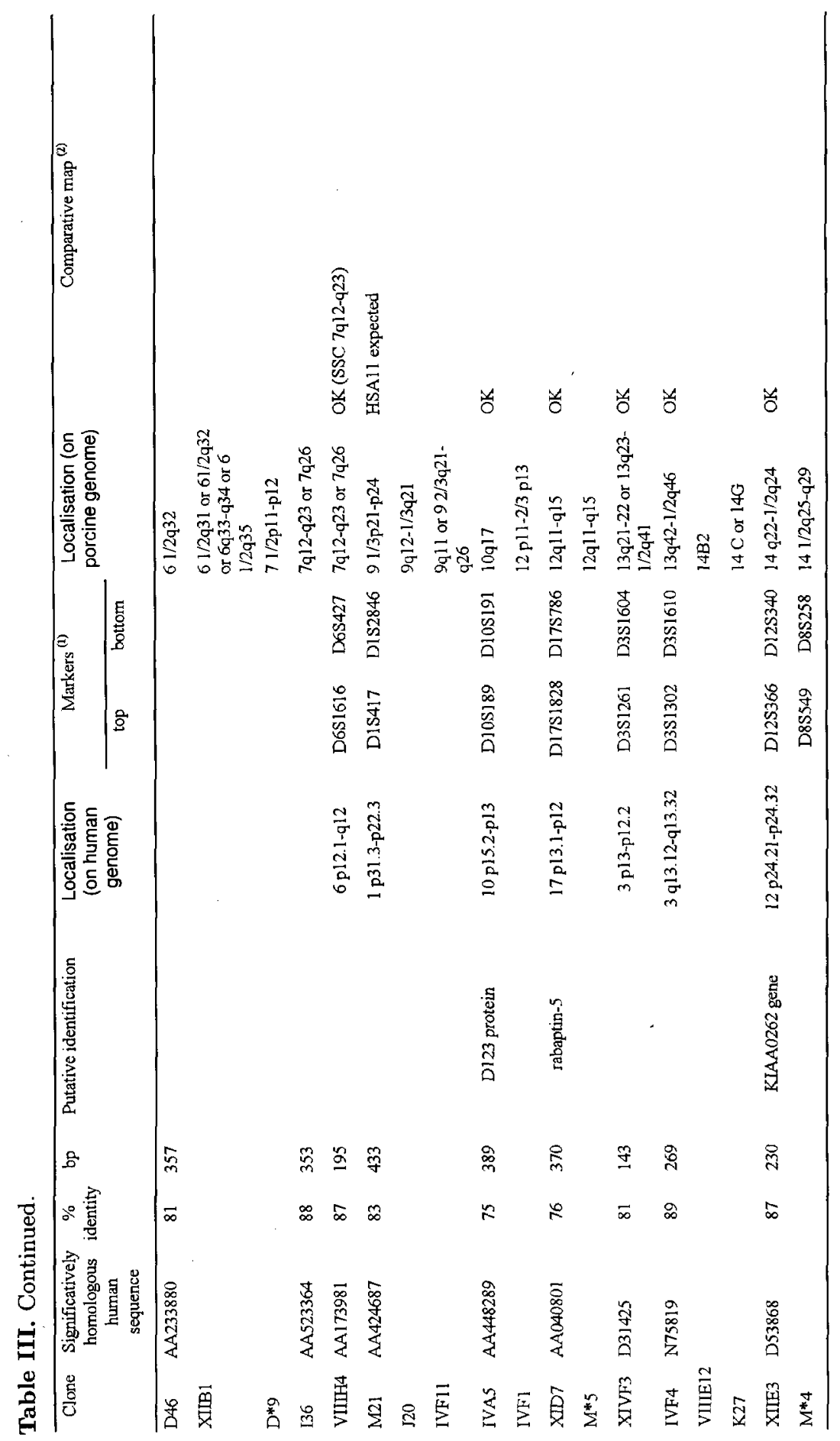




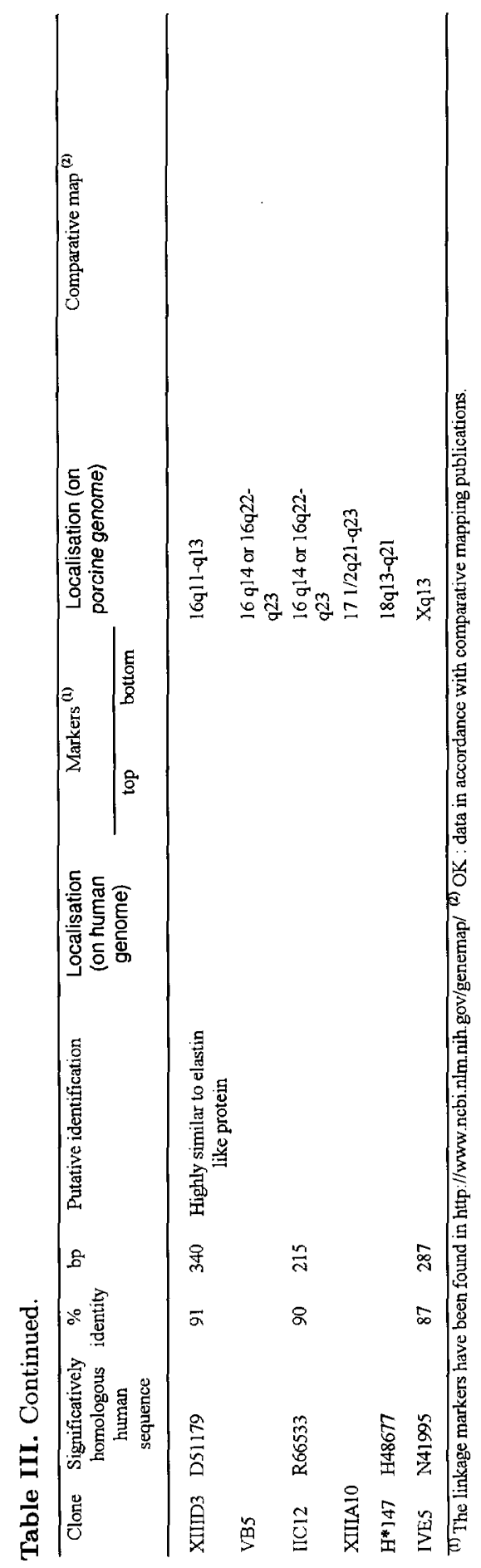


The sequences of our PCR primers were found on the human sequence ( $5^{\prime}$ coding region, sequence AF046024). But the three primer pairs (Gene Map 98 data) that permitted the mapping of AF046024 onto the human irradiated panel on Hsap3 are situated at the $3^{\prime}$-end of the human sequence and were not found in our pig $3^{\prime}$-end sequence without a mismatch. So, since the $5^{\prime}$ sequence of a gene can be found in several genes of the same family (with a specific $3^{\prime}$ end), we may have localised another member of the family, sharing part of its $5^{\prime}$-end sequence with the human AF046024 sequence.

\section{4. $\operatorname{Sscr} 3$}

VIIA12 was localised on Sscr3 p16-p17 or 3q12 and the corresponding human sequence was localised on Hsap2. This was in accordance with heterologous painting experiments $[7,21]$ which demonstrate a correspondence between Sscr3 q11-q12 and Hsap2. For Sscr3p15-p17, only one team gives a correspondence with Hsap16 [7] and the localisation of two other markers on Sscr3p15-p17 (EPO, ZP3) suggests a correspondence with Hsap7. This suggests that VIIA12 is most probably localised on Sscr3 q12 and confirms the correspondence between Sscr3 q12 and Hsap2.

The localisation of C134 suggests a correspondence of Sscr3 q11 with Hsap3 or 9 , since the D80005 human sequence which is similar to C134 has been mapped onto these chromosomes. Moreover, the sequence of our primers was found (with only one mismatch, in the middle of the primers) on the D80005 mRNA sequence of the KIAA0183 gene (position 4710 and 4828 ) mapped onto Hsap3 or 9. Other neighboring markers should be mapped to confirm this new correspondence, since two of the three painting experiments [7,21] have found this zone to be in correspondence with Hsap2 [7]; Goureau et al. did not obtain any painting signal in this zone [9].

\subsection{Sscr5, Sscr9 and Sscr16}

The localisation of M19 on Sscr5 q25 suggests that this zone, unpainted according to Goureau et al. [9] is in correspondence with Hsap12, as suggested by Rettenberger et al. [21] and Frönicke et al. [7]. Lahbib-Mansais et al. [14] found the same result for one human EST (D29485).

The localisation of M21 on Sscr9 1/3p21-p24 suggests a correspondence between Sscr9 and Hsap1. This has also been suggested by the localisation of MYOG [5]. This result should be confirmed by the localisation of neighbouring ESTs.

$E^{*} 9$ was mapped on Sscr3 with a 0.72 probability (2 discordant results). Its localisation on Sscr16 however, had a 0.16 probability ( 3 discordant results), with a 0.78 correlation coefficient, but was in agreement with the heterologous painting experiments. This was due to the very similar representation of these regions of Sscr3 and Sscr16 in the somatic cell hybrid panel.

Altogether, these results improved the transcriptional porcine map of most chromosomes. This data will generate new results since the human map is still in progress and new homologies between porcine and human genomes will be found. 
For the results that show discrepancies with the human map, more data is required. These markers could be mapped on the porcine irradiated hybrid panel characterised by Hawken et al. [12]. Furthermore, other markers should be mapped in the same region to confirm new correspondences between the porcine and human genomes. Alternatively, genetic mapping could be used, if a polymorphism is found in the porcine genes to be mapped.

These localisations of coding sequences will be useful when Quantitative Trait Loci (QTL) are identified more precisely, since some candidates will have been localised in the region of interest. Moreover, since our cDNAs were isolated from ovarian tissue and some of them are regulated by $\mathrm{FSH}$, they will be good candidates for reproductive traits.

\section{ACKNOWLEDGEMENTS}

We would like to thank Janine Rallières and Francis Benne for technical assistance and Elsa Bonnafé, Laure Caussanel, Virginie Gindraud, and Sylvie Perret for regional mapping. We also thank Hélène Quesnel (Unité mixte de recherche sur le veau et le porc, INRA) who provided the ovaries of cycled sows.

\section{REFERENCES}

[1] Andersson L., Haley C.S., Ellegren H., Knott S.A., Johansson M., Andersson K., Andersson-Eklund L., Edfors-Lilja I., Fredholm M., Hansson I. et al., Genetic mapping of quantitative trait loci for growth and fatness in pigs, Science 263 (1994) 1771-1774.

[2] Callard D., Mazzolini L., Identification of proliferation-induced genes in Arabidopsis thaliana. Characterization of a new member of the highly evolutionarily conserved histone H2A.F/Z variant subfamily, Plant Physiol. 115 (1997) 13851395.

[3] Chevalet C., Gouzy J., San Cristobal-Gaudy M., Regional assignment of genetic markers using a somatic cell hybrid panel: a WWW interactive program available for the pig genome, Comput. Appl. Biosci. 13 (1997) 69-73.

[4] Erickson G.F., Primary cultures of ovarian cells in serum-free medium as models of hormone-dependent differentiation, Mol. Cell. Endocr. 29 (1983) 21-49.

[5] Ernst C.W., Mendez E.A., Robic A., Rothschild M.F., Rapid communication: myogenin (MYOG) physically maps to porcine chromosome 9q2.1-q2.6, J. Anim. Sci. 76 (1998) 328.

[6] Fridolfsson A.K., Hori T., Winterø A.K., Fredholm M., Yerle M., Robic A., Andersson L., Ellegren H., Expansion of the pig comparative map by expressed sequence tags (EST) mapping, Mamm. Genome 8 (1997) 907-912.

[7] Frönicke L., Chowdhary B.P., Scherthan H., Gustavsson I., A comparative map of the porcine and human genomes demonstrates ZOO- FISH and gene mappingbased chromosomal homologies, Mamm. Genome 7 (1996) 285-290.

[8] Gellin J., Barillot E., Chowdhary B.P., Davoli R., Fredholm M., Hatey F., Wimmer K., Mapping and identification of 700 genes in the pig genome, a European initiative, Anim. Genet. 29 (1998) 37. 
[9] Goureau A., Yerle M., Schmitz A., Riquet J., Milan D., Pinton P., Frelat G., Gellin J., Human and porcine correspondence of chromosome segments using bidirectional chromosome painting, Genomics 36 (1996) 252-262.

[10] Hatey F., Gasparoux J.P., Mulsant P., Bonnet A., Gasser F., P450scc regulation in pig granulosa cells: investigation into the mechanism of induction, J. Steroid Biochem. Mol. Biol. 43 (1992) 869-874.

[11] Hatey F., Langlois I., Mulsant P., Bonnet A., Benne F., Gasser F., Gonadotropins induce accumulation of insulin-like growth factor I mRNA in pig granulosa cells in vitro, Mol. Cell. Endocr. 86 (1992) 205-211.

[12] Hawken R.J., Murtaugh J., Flickinger G.H., Yerle M., Robic A., Milan D., Gellin J., Beattie C.W., Schook L.B., Alexander L.J., A first-generation porcine wholegenome radiation hybrid map, Mamm. Genome 10 (1999) 824-830.

[13] Jørgensen C.B., Winter $\varnothing$ A.K., Yerle M., Fredholm M., Mapping of 22 expressed sequence tags isolated from a porcine small intestine cDNA library, Mamm. Genome 8 (1997) 423-427.

[14] Lahbib-Mansais Y., Dalias G., Milan D., Yerle M., Robic A., Gyapay G., Gellin J., A successful strategy for comparative mapping with human ESTs: 65 new regional assignments in the pig, Mamm. Genome 10 (1999) 145-153.

[15] Lanneluc I., Mulsant P., Saidi-Mehtar N., Elsen J.M., Synteny conservation between parts of human chromosome $4 \mathrm{q}$ and bovine and ovine chromosomes 6 , Cytogenet. Cell Genet. 72 (1996) 212-214.

[16] Lino J., Baranao S., Hammond J.M., Multihormone regulation of steroidogenesis in cultured porcine granulosa cells: studies in serum-free medium, Endocrinology 116 (1985) 2143-2151.

[17] Makalowski W., Zhang J., Boguski M.S., Comparative analysis of 1196 orthologous mouse and human full-length mRNA and protein sequences, Genome Res. 6 (1996) 846-857.

[18] Monget P., Monniaux D., Pisselet C., Durand P., Changes in insulin-like growth factor-I (IGF-I), IGF-II, and their binding proteins during growth and atresia of ovine ovarian follicles, Endocrinology 132 (1993) 1438-1446.

[19] Pearson W.R., Lipman D.J., Improved tools for biological sequence comparison, Proc. Natl. Acad. Sci., USA 85 (1988) 2444-2448.

[20] Pinton P., Schibler L., Cribiu E., Gellin J., Yerle M., Localisation of 113 anchor loci in pigs: improvement of the comparative map for humans, pigs and goats, Mamm. Genome 11 (2000) 306-315.

[21] Rettenberger G., Klett C., Zechner U., Kunz J., Vogel W., Hameister H., Visualization of the conservation of synteny between humans and pigs by heterologous chromosomal painting, Genomics 26 (1995) 372-378.

[22] Robic A., Riquet J., Yerle M., Milan D., Lahbib-Mansais Y., Dubut-Fontana C., Gellin J., Porcine linkage and cytogenetic maps integrated by regional mapping of 100 microsatellites on somatic cell hybrid panel, Mamm. Genome 7 (1996) $438-445$.

[23] Saumande J., Culture of bovine granulosa cells in a chemically defined serumfree medium: the effect of insulin and fibronectin on the response to FSH, J. Steroid Biochem. Mol. Biol. 38 (1991) 189-196:

[24] Tosser-Klopp G., Benne F., Bonnet A., Mulsant P., Gasser F., Hatey F., A first catalog of genes involved in pig ovarian follicular differentiation, Mamm. Genome 8 (1997) 250-254.

[25] Wilkie P.J., Paszek A.A., Beattie C.W., Alexander L.J., Wheeler M.B., Schook L.B., A genomic scan of porcine reproductive traits reveals possible quantitative 
trait loci (QTLs) for number of corpora lutea, Mamm. Genome 10 (1999) 573578.

[26] Winter $\varnothing$ A.K., Fredholm M., Davies W., Evaluation and characterization of a porcine small intestine cDNA library: analysis of 839 clones, Mamm. Genome 7 (1996) 509-517.

[27] Winterø A.K., Jørgensen C.B., Robic A., Yerle M., Fredholm M., Improvement of the porcine transcription map: localization of 33 genes, of which 24 are orthologous, Mamm. Genome 9 (1998) 366-372.

[28] Yerle M., Echard G., Robic A., Mairal A., Dubut-Fontana C., Riquet J., Pinton P., Milan D., Lahbib-Mansais Y., Gellin J., A somatic cell hybrid panel for pig regional gene mapping characterized by molecular cytogenetics, Cytogenet. Cell Genet. 73 (1996) 194-202.

[29] Yerle M., Pinton P., Robic A., Alfonso A., Palvadeau Y., Delcros C., Hawken R., Alexander L., Beattie C., Schook L., Milan D., Gellin J., Construction of a whole-genome radiation hybrid panel for high-resolution gene mapping in pigs, Cytogenet. Cell Genet. 82 (1998) 182-188.

To access this journal on line: www.edpsciences.org 